\title{
PENGARUH INDEPENDENSI, PENGALAMAN DAN PROFESIONALISME AUDITOR TERHADAP KUALITAS AUDIT PADA KAP DBSD\&A
}

\author{
Farah Fajriyah $^{1)}$ Esti Damayanti ${ }^{2)}$ \\ Program Studi Akuntansi Fakultas Ekonomi \\ Universitas Krisnadwipayana \\ farah.fajriyah@gmail.com ${ }^{1)}$ \\ estidamayanti1678@gmail.com ${ }^{2}$
}

\begin{abstract}
This study aims to determine the influence of Independency, Experience and Professionalism Auditor on Audit Quality at public accounting firm Doli, Bambang, Sulistiyanto, Dadang \& Ali.

Sampling Method This research uses purposive sampling method in criteria: a. Auditors working in the Public Accounting Firm Doli, Bambang, Sulistiyanto, Dadang \& Ali within a period of at least 6 months, $b$. Auditors have expertise in the field of audit and thoroughness in making audit reports, $c$. Auditor who has carried out auditing work within a period of at least 6 months. $d$. Auditors who have at least D3 level of education, $e$. Auditor who has a position equivalent partner, manager and supervisor auditing, $f$. Auditor working in Public Accounting Firm registered in Indonesian Institute of Certified Public Accountants Directory.

Questionnaires are distributed as many as 26 questionnaires with a return rate of 17 respondents from 6 Public Accounting Firm. The data is analyzed by multiple regression method and processed with SPSS version 22 program. Data analysis is equipped with data quality test and classical assumption test.The results of this study indicate that Independence, Experience and Professionalism Auditors significantly influence audit quality. this research also shows that experience variable is the most dominant variable affecting audit quality.
\end{abstract}

Keyword : Independence, Experience, Professionalism, Audit Quality.

\section{PENDAHULUAN}

Perusahaan membutuhkan jasa audit untuk memeriksa laporan keuangan yang telah dihasilkan. Perusahaan menggunakan jasa audit untuk menyampaikan informasi mengenai pertanggung jawaban pengelolaaan dana yang berasal dari pihak luar sedangkan pihak eksternal menggunakan laporan keuangan yang telah di audit tersebut untuk melakukan penilaian dan pengambilan keputusan tentang hubungan mereka dan perusahaan. Baik klien yang menggunakan jasa audit ataupun pihak eksternal pengguna laporan audit menaruh banyak kepercayaan terhadap hasil audit yang telah dihasilkan oleh auditor tersebut. Dengan adanya kepercayaan dari pihak klien maupun pihak eksternal diharapkan auditor dapat menjaga kepercayaan tersebut dengan baik.
Auditor dalam melakukan jasa audit harus menyajikan laporan tersebut sesuai dengan apa yang terjadi dan tidak menyesatkan pengguna laporan tersebut. Dengan menjaga kepercayaan tersebut maka akan menjaga nama baik auditor maupun kantor akuntan publik tempatnya bekerja. Auditor dituntut untuk terus menjaga kepercayaan dan menjaga kualitas audit dengan baik. Untuk dapat menjaga kepercayaan dan kualitas audit, maka auditor dalam melaksanakan jasa audit harus berpedoman pada standart audit yang telah ada. Saat ini indonesia sudah mengadopsi International Standar on auditing yang dapat digunakan oleh kantor akuntan publik dalam memberikan jasa tersebut. Dengan melakukan pengauditan sesuai prosedur dan pedoman yang ada di harapkan hasil audit yang dihasilkan dapat di percaya oleh pengguna laporan keuangan. 
Selama pekerjaan audit berlangsung, auditor akan sering melakukan interaksi secara profesional dengan pihak manajemen klien. Namun perlu ditekankan bawah mempercayai manajemen tidak berarti auditor mempercayainya dengan mudah. Dalam melakukan auditnya, auditor dituntut untuk selalu memiliki sikap skeptis terhadap asersi atau pernyataan-pernyataan yang dibuat oleh manajemen.

Independensi merupakan salah satu faktor yang paling berpengaruh terhadap pekerjaan audit dan hasil audit tersebut. Independensi juga merupakan sesuatu hal yang harus dijunjung dan diterapkan oleh auditor dalam melaksanakan tugasnya. Independensi berarti para auditor tidak mudah dipengaruhi oleh siapapun ataupun apapun itu. Banyak hal-hal yang mempengaruhi berkurangnya independensi auditor salah satunya yaitu telah melaksanakan jasa audit tersebut pada perusahaan lebih dari satu tahun, selain itu independensi juga akan berkurang jika melakukan pengauditan kepada klien yang mempunyai hubungan keluarga terhadap auditor. Dengan adanya independensi pada seorang auditor maka hasil laporan audit dapat dipercaya karena telah menunjukkan informasi yang jujur.

Selain independensi, pengetahuan auditor akan semakin berkembang seiring bertambahnya pengalaman melakukan tugas audit. Para auditor yang memiliki pengalaman yang lebih banyak dapat membantu para auditor pemula mengerjakan tugasnya dengan cara memeriksa hasil pekerjaan para auditor pemula. Untuk melaksanakan tugasnya para auditor yang memiliki pengalaman memiliki cara berpikir yang lebih terperinci dan lengkap serta dapat mengambil keputusan yang tepat pada saat audit di klien, dibandingkan yang belum berpengalaman. Untuk pengalaman yang dimaksud itu seperti lamanya auditor bekerja, banyaknya laporan audit yang telah diselesaikan dan beraneka ragam jenis industri perusahaan yang yang pernah diaudit. Dengan banyaknya pengalaman yang telah didapatkan oleh auditor maka auditor akan lebih sadar menemukan kekeliruan dan akan semakin teliti dalam menyelesaikan tugasnya maka akan menambah nilai kualitas sebuah hasil audit.

Profesionalisme merupakan suatu keharusan bagi seorang auditor dalam menjalankan tugasnya. Profesionalisme dapat memberi keyakinan terhadap laporan keuangan bagi sebuah perusahaan atau organisasi dimana auditor bekerja. Oleh karena itu auditor dituntut untuk profesional dalam setiap tugas. Auditor yang memiliki pandangan profesionalisme yang tinggi akan memberikan kontribusi yang dapat dipercaya oleh para pengambil keputusan.

Kualitas audit merupakan hasil temuantemuan yang didapat oleh auditor dalam laporan keuangan klien. Kualitas audit sebagai probabilitas dimana seorang auditor menemukan dan melaporkan tentang adanya suatu pelanggaran dalam sistem akuntansi kliennya. Kualitas audit merupakan suatu issue yang komplek, karena begitu banyak faktor yang dapat mempengaruhi kualitas audit, tergantung dari sudut pandang masing-masing pihak. Hal tersebut menjadikan kualitas audit sulit pengukurannya, sehingga menjadi suatu hal yang sensitif bagi perilaku individual yang melakukan audit. Kualitas audit bisa juga dilihat dari kualitas keputusan-keputusan yang diambil. Selain independensi, pengalaman, dan profesionalisme auditor masih banyak lagi halhal yang berpengaruh terhadap kualitas audit tersebut seperti standar etika yang tinggi, bersikap hati-hati, melibatkan pimpinan atau rekan kantor akuntan publik, memahami industri klien, reputasi kantor akuntan publik, dan responsive terhadap kebutuhan klien. Dengan semakin tingi nilai kualitas audit maka kepercayaan pengguna laporan keuangan audit akan semakin tinggi juga. Dengan begitu diharapkan para auditor dapat melaksanakan tugasnya dengan baik agar mendapatkan kualitas audit yang tinggi.

Berdasarkan uraian mengenai latar belakang yang telah dikemukakan di atas, maka peneliti tertarik untuk meneliti bagaimana pengaruh independensi, pengalaman, profesionalisme auditor terhadap kualitas auditor serta faktor manakah dari ketiga hal tersebut (independensi, pengalaman, dan profesionalisme) yang paling mempengaruhi kualitas hasil audit pada KAP DBSD \&A

\section{TINJAUAN PUSTAKA}

Independensi menurut (Sukrisno,2012:33) didefinisikan sebagai kepercayaan masyarakat umum atas independensi sikap auditor 
independen sangat penting bagi perkembangan profesi akuntan publik ,kepercayaan masyarakat akan menurun jika terdapat bukti bahwa independensi sikap auditor ternyata berkurang, bahkan kepercayaan masyarakat dapat juga menurun disebabkan oleh keadaan yang mereka berpikiran sehat dianggap dapat mempengaruhi sikap independen tersebut.

Untuk menjadi independen auditor harus intelektual jujur, untuk diakui pihak lain sebagai orang yang independen, auditor harus bebas dari setiap kewajiban terhadap kliennya dan tidak mempunyai suatu kepentingan dengan kliennya, apakah itu manajemen perusahaan atau pemilik perusahaan. Auditor tidak sama sekali pengaruh terhadap fasilitas yang disediakan oleh klain tersebut.

Pengertian Independensi menurut Amin (2016:20) adalah auditor menempatkan independensi pada tingkat yang paling tinggi. Independensi memungkinkan auditor untuk membuat keputusan yang bias dalam memberikan jasa kepada entitas. Auditor merupakan karyawan penuh waktu dari entitas yang diaudit. Menurut Kovinna dkk (2014) sikap mental independen harus meliputi independence in fact dan independence. Independen dalam fakta adalah inpenden dalam diri auditor, yaitu kemampuan auditor untuk bersikap bebas, jujur dan objektif dalam melakukan penugasan audit. independen dalam penampilan adalah independen yang di pandang dari pihak-pihak yang berkepentingan terhadap perusahaan yang diaudit yang diketahui hubungan antara auditor dengan kliennya seperti mempunyai saham pada perusahaan yang diaudit.

Menurut Mathius (2016:169) independen adalah standar audit yang esensial untuk menunjukkan kredibilitas laporan keuangan yang menjadi tanggung jawab manajemen. Dalam proses audit klien tidak berhak ikut campur kecuali informasi yang dibutuhkan. Ia menekankan bahwa jika akuntan tidak bersikap indepeden, maka opini yang diberikannya tidak akan memberi tambahan nilai apa pun. Kewajiban ini harus dijalankan oleh akuntan walaupun hal tesebut harus bertentangan dengan keinginan pihak yang menyewa mereka yang mungkin saja kemudian akan memecat mereka. Tidak hanya menekankan pada nilai penting dari independen terhadap pengauditan, tetapi dari segi tampilan dan kenyataan.

Menurut (Gunasti:2013) independen berarti tidak mudah dipengaruhi dan tidak memiliki kepentingan dan tidak memiliki kepentingan pribadi dalam pelaksanaan tugasnya seorang audit tidak dibenarkan memihak kepada kepentingan siapapun dan independensi auditor tidak akan terganggu dengan adanya rekan yang sedang melakukan review atas hasil audit. Faktor lainnya yang juga mempengaruhi independensi auditor adalah tekanan dari klien. Pada kondisi ini, auditor berada pada posisi yang dilematis dimana pada satu sisi auditor harus melakukan audit sesuai dengan aturan dan etika profesi yang ditetapkan, namun di sisi lain, independensi tidak juga tergantung pada klien yang memberikan fee tinggi atau rendah dalam kesesuaian audit.

Pengertian pengalaman auditor menurut Messier (2014:34) adalah mendeteksi kesalahan, memahami kesalahan secara akurat, mencari penyebab kesalahan.

Hasil yang menunjukkan bahwa semakin berpengalaman auditor, mereka semakin peka dengan kesalahan, semakin peka dengan kesalahan yang tidak biasa dan semakin memahami hal-hal lain yang terkait dengan kesalahan ditemukan. Pengertian lain mengenai pengalaman auditor menurut Tjun-Tjun (2012:27) adalah memberikan bukti empiris bahwa seseorang yang berpengalaman dalam suatu bidang subtantif memiliki lebih banyak hal yang tersimpan dalam ingatannya. Semakin banyak pengalaman seorang audit, akan menghasilkan hasil yang akurat dan lebih banyak mempunyai memori tentang struktur kategori yang rumit. Ida Suraida (2013) mendefinisikan pengalaman adalah yang dimiliki auditor, membuat auditor akan lebih memahami dan mengetahui berbagai masalah secara lebih mendalam dan mengatasi setiap masalah yang ada dapat tercermin dari banyaknya penugasan audit yang pernah di lakukan tahun tahun sebelumnya.

Dari beberapa definisi mengenai pengalaman auditor dapat disimpulkan bahwa semakin banyak pengalaman kerja seorang auditor maka semakin meningkat kualitas hasil pemeriksaan yang dilakukan. Seseorang yang melakukan pekerjaan sesuai dengan pengetahuan yang dimilikinya akan memberikan hasil yang 
baik daripada mereka yang tidak memiliki pengetahuan yang cukup dalam menjalankan tugasnya. Kenyataan menunjukkan bahwa semakin lama seseorang bekerja dalam berbagai macam industri, maka semakin banyak pengalaman yang dimiliki pekerjaan tersebut dalam kualitas audit. Sebaliknya, semakin singkat masa kerja berarti semakin sedikit pengalaman yang diperolehnya. Pengalaman bekerja memiliki keahlian meminimalkan kesalahan dalam tugas audit dan keterampilan kerja yang cukup namun sebaliknya, keterbatasan kerja mengakibatkan tingkat keterampilan dan keahlian yang dimiliki semakin rendah. Kebiasaan untuk melakukan tugas dan pekerjaan sejenis merupakan sarana positif untuk meningkatkan keahlian tenaga kerja dan menyelesaikan tugas audit dalam waktu yang tepat.

Profesionalisme auditor menurut Haryono (2014:171) skeptisisme profesional terdiri dari dua komponen utama, yaitu:

1. Suatu pikiran yang selalu mempertanyakan

2. Sikap waspada atau kritis dalam menilai bukti audit

Walaupun auditor bersikap percaya bahwa organisasi yang telah diterimanya sebagai klien memiliki integritas dan jujur, namun dengan selalu berpikiran mempertanyakan akan membantu auditor dalam menghilangkan bias alami untuk percaya pada klien. Sikap selalu mempertanyakan adalah pendekatan audit auditor dengan pandangan mental "percaya tetapi tetap memeriksa" (trust but verify). Demikian pula ketika mendapatkan dan mengevaluasi bukti bukti pendukung tentang jumlah-jumlah dan pengungkapan dalam laporan keuangan, skeptisisme profesional juga meliputi penilaian kritis atas bukti-bukti yang mencakup pertanyaan yang menyelidik dan perhatian terhadap kemungkinan konsistensi. Apabila auditor melaksanakan tanggung jawabnya dengan menjaga sikap berpikir mempertanyakan dan secara kritis mengevaluasi bukti, auditor akan dapat mengurangi secara signifikan kemungkinan kegagalan audit selama audit berlangsung.

Menurut Baotham (2013) profesionalisme juga menjadi syarat utama sebagai auditor kemampuan didefinisikan sebagai pengetahuan, tidak cepat percaya sebelum menemukan bukti, pengalaman kemampuan beradaptasi, kemampuan teknis dan memiliki sikap waspada terhadap kemungkinan terjadinya salah saji dalam laporan keuangan. Sedangkan menurut Arens et al (2012) profesionalisme merupakan tanggung jawab berperilaku yang lebih dari sekedar tanggung jawab yang diberikan pada auditor dan lebih dari untuk mengikuti peraturan undang-undang (tertulis) dan peraturan masyarakat (tidak tertulis) sebagai seorang individu yang profesional, auditor harus mempunyai pikiran yang selalu mempertanyakan terkait dengan laporan keuangan yang diauditnya dan auditor mengakui tanggung jawab terhadap manajemen dan organisasi klien terhadap rekan seprofesi termasuk berperilaku sekalipun.

Berdasarkan teori tentang profesionalisme dapat disimpulkan bahwa pada intinya profesionalisme merupakan sikap tanggung jawab terhadap apa yang telah ditugaskan kepadanya dalam menentukan pendapat atas laporan keuangan auditor tidak mendapatkan tekanan dari pihak mana pun sikap profesionalisme akan mengambil keputusan berdasarkan pertimbangan yang dimiliknya auditor membuat penaksiran yang kritis terhadap validitas dari bukti audit yang diperoleh agar laporan tersebut bisa di pakai oleh pihak berkepentingan

Kualitas audit menurut Agusti (2013:3) Kualitas Audit adalah merupakan segala kemungkinan dimana auditor pada saat mengaudit laporan keuangan klien dapat menemukan pelanggaran yang terjadi dalam sistem akuntansi klien dan melaporkannya dalam bentuk laporan keuangan audit, dimana dalam melaksanakan tugasnya tersebut auditor berpedoman pada standart auditing dan laporan audit harus sesuai dengan kondisi audit dengan hasil temuan. Menurut Rusmawan (2013) kualitas audit didefinisikan sebagai ditentukan oleh kompentensi (pendidikan dan pengalaman) dan kepatuhan auditor terhadap SPBU (Standar Pengauditan Berterima Umum) serta auditor memiliki komitmen yang kuat untuk menyelesaikan audit dalam tepat waktu. Oleh karena itu, seharusnya kualitas laporan audit yang dihasilkan sama karena dasar pendidikan auditor sama. Oleh sebab itu proses pengumpulan dan pengujian bukti harus dilakukan dengan maksimal untuk mendukung kesimpulan temuan audit serta rekomendasi terkait. 
Djara, et al (2013) mengungkapkan langkahlangkah yang dapat dilakukan untuk meningkatkan kualitas audit adalah:

a. Dalam melaksanakan pekerjaan audit, auditor menggunakan kemahiran profesionalnya dengan cermat dan seksama.

b. Kualitas audit berkaitan dengan ketepatan auditor dalam memberikan opini

c. Melakukan perencanaan pekerjaan audit dengan baik.

d. Audit selalu berusaha hati hati dalam pengambilan keputusan selama melakukan audit.

e. Memperoleh bukti audit yang cukup dan kompeten.

f. Laporan yang dihasilkan harus akurat, lengkap, objektif, meyakinkan, jelas, ringkas agar informasi yang diberikan bermanfaat secara maksimal.

g. Mempertahankan independensi dalam sikap mental

h. Auditor Mempelajari laporan tahun sebelumnya sebelum melakukan audit ke klien.

Bagi suatu Kantor Akuntan Publik standar pengendalian kualitas audit terdiri dari metodemetode yang digunakan untuk pemahaman terhadap pengendalian intern klien dapat menjadikan pelaporan audit lebih baik dan memastikan bahwa kantor itu memenuhi tanggung jawab profesionalnya kepada klien.

\section{METODOLOGI PENELITIAN}

Objek yang digunakan dalam penelitian ini adalah para auditor yang bekerja di Kantor Akuntan Publik Doli, Bambang, Sulistiyanto, Dadang \& Ali. Penelitian ini dilakukan pada bulan Juni 2017 - Agustus 2017. Secara lebih rinci operasional variabel penelitian adalah independensi, pengalaman dan profesionalisme terhadap kualitas audit.

Selanjutnya variabel paten ini diukur berdasarkan indikator yaitu:

Tabel 1. Indikator Variabel

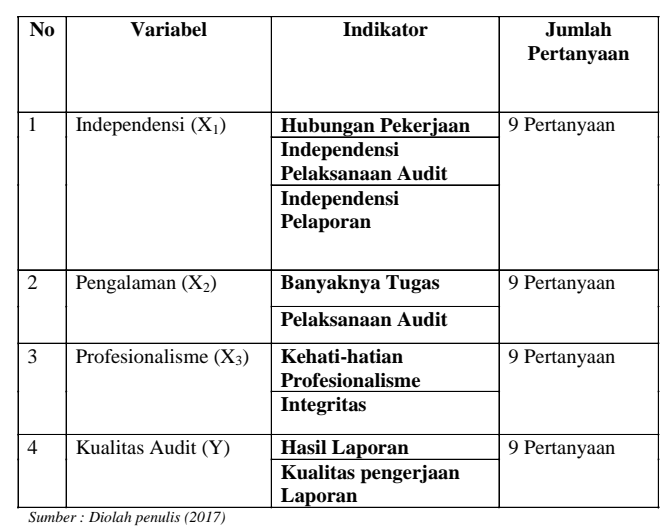

Instrumen penelitian yang digunakan dalam penelitian ini adalah metodelogi kuantitatif. Metode kuantitatif digunakan untuk mendapatkan data dan melakukan analisis data dengan prosedur statistik. Peneliti mendapatkan data dari kuesioner yang telah disebarkan.

Secara umum, populasi dalam penelitian ini dibatasi hanya pada kantor Akuntan publik Doli, Bambang, Sulistiyanto, Dadang \& Ali yang tercantum dalam catatan Institut Akuntan Publik Indonesia (IAPI). Dimana populasi sebanyak 17 auditor sedangkan yang menjadi responden adalah 8 Responden Supervisor, 3 Responden Partner dan 6 Responden Manager.

Sampel penelitian yang diambil sebanyak 6 KAP dari jumlah 9 KAP Doli, Bambang, Sulistiyanto, Dadang \& Ali. Dikarenakan jumlah manajer dan partner disetiap kantor akuntan publik sedangkan yang menjadi responden adalah 17 responden sedangkan yang menjadi responden adalah 8 Responden Supervisor, 3 Responden Partner dan 6 Responden Manager dengan menggunakan metode purposive sampling yaitu sampling diperoleh dengan menggunakan pertimbangan atau kriteria tertentu yang umumnya disesuaikan dengan tujuan atau masalah penelitian.

Kriteria sampel yang digunakan dalam penelitian ini adalah :

a. Auditor yang bekerja di Kantor Akuntan Publik Doli, Bambang, Sulistiyanto, Dadang \& Ali dalam jangka waktu minimal 6 bulan.

b. Auditor memiliki keahlian di bidang audit dan ketelitian dalam membuat laporan audit. 
c. Auditor yang sudah melaksanakan pekerjaan dibidang auditing dalam jangka waktu minimal 6 bulan.

d. Bersedia menjadi responden dalam penelitian.

e. Memiliki latar belakang pendidikan minimal D3 Akuntansi.

f. Auditor yang memiliki jabatan setara partner, manager dan supervisor auditing.

g. Auditor yang bekerja di Kantor Akuntan Publik yang terdaftar pada Direktori Ikatan Akuntan Publik Indonesia.

Teknik pengumpulan data dilakukan dengan observasi berperan serta, yaitu peneliti terlibat dengan kegiatan sehari-hari orang yang sedang diamati atau yang digunakan sebagai sumber data penelitian. Tahap kedua, para auditor mengisi data diri dan menjawab pertanyaanpertanyaan yang ada dalam kuesioner tersebut kemudian peneliti mengumpulkan kuesioner tersebut untuk diolah menjadi data. Pengukuran jawaban kuesioner menggunakan skala likert lima point. Skala likert adalah sebuah pernyataan dimana responden diminta untuk mengevaluasi tingkatan persetujuan atau ketidaksetujuan. Semakin tinggi nomor jumlah, semakin besar variabel independen mempengaruhi variabel dependen.

Pada penelitian ini dilakukan dengan membagikan kuesioner ke 9 Kantor Akuntan Publik Doli, Bambang, Sulistiyanto, Dadang \& Ali.

Skala likert yang digunakan dalam penelitian ini adalah :

$1=$ Sangat Tidak Setuju (STS)

$2=$ Tidak Setuju (TS)

$3=\operatorname{Netral}(\mathrm{N})$

$4=$ Setuju (S)

5= Sangat Setuju (SS)

Pada saat analisis data setelah semua data-data dalam penelitian terkumpul, maka selanjutnya dilakukan pengelolahan data dengan bantuan perangkat lunak SPSS for windows 22.0. metode statistik yang digunakan untuk menguji hipotesis adalah dengan menggunakan analisis regresi berganda. Analisis regrensi berganda bermanfaat untuk mengetahui pengaruh variabel independen terhadap variabel dependen. Selain itu, regresi juga digunakan untuk membuktikan hipotesis yang telah dirumuskan.

\section{HASIL DAN PEMBAHASAN}

Independensi, Pengalaman, dan Profesionalisme Berpengaruh Terhadap kualitas Audit (uji F)

Langkah-langkah melakukan uji F sebagai berikut:

1. Menentukan Hipotesis

Ho : tidak terdapat pengaruh signifikan antara independensi, pengalaman dan profesionalisme auditor secara bersama-bersama terhadap kualita audit.

Ha : terhadap pengaruh signifikan antara Independensi, Pengalaman dan Profesionalisme auditor secara bersama-sama terhadap kualitas audit.

2. Menentukan tingkat signifikansi Tingkat signifikansi menggunakan $\alpha=$ $5 \%$

3. Menentukan F hitung

Tabel 2.

Uji Koefisien Regresi Simultan

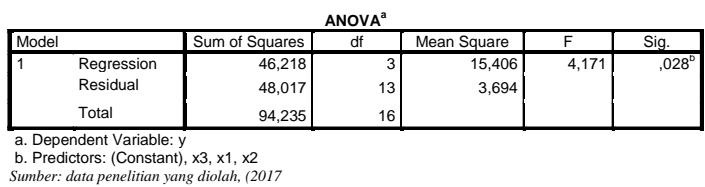

Berdasarkan tabel 2 diperoleh $F$ hitung sebesar 4,171 .

4. Menentukan F tabel

Tabel distribusi t dicari pada nilai $\alpha=$ 0.05 dan df $2=13$ (didapat dari rumus $n$ $\mathrm{k}$, dimana $\mathrm{n}$ adalah jumlah data, 17-4=13) kemudian mendapatkan $\mathrm{F}_{\text {tabel }}$ dengan nilai. 3,41.

5. Kriteria pengujian Ho diterima jika $\mathrm{F}$ hitung $<\mathrm{F}$ tabel Ha diterima jika $\mathrm{F}$ hitung $>\mathrm{F}$ tabel

6. Membandingkan $\mathrm{F}$ hitung dengan $\mathrm{F}$ tabel

Nilai F hitung > F tabel $(4,171>3.41)$ maka Ha diterima.

7. Kesimpulan Nilai $F$ hitung $>F$ tabel $(4,171>3.41)$ dan nilai sig. Lebih kecil dari $0,05(0,000<0,5)$, maka Ho ditolak dan $\mathrm{Ha}$ diterima, artinya terdapat 
pengaruh signifikan antara independensi, pengalaman dan profesionalisme auditor secara bersama-sama terhadap kualitas audit.

\section{Independensi Berpengaruh Terhadap kualitas audit (Uji Statistik t)}

Langkah-langkah pengujian sebagai berikut:

1. Menentukan Hipotesis

Ho : secara parsial tidak terdapat pengaruh signifikan antara Independensi auditor terhadap kualitas audit.

$\mathrm{Ha}$ : secara parsial terdapat pengaruh signifikan antar Independensi auditor terhadap kualitas audit.

2. Menentukan tingkat signifikansi

Tingkat signifikansi menggunakan $\alpha=$ $5 \%$

3. Menentukan t hitung

\section{Tabel 3.}

Uji Koefisien Regresi Indpendensi

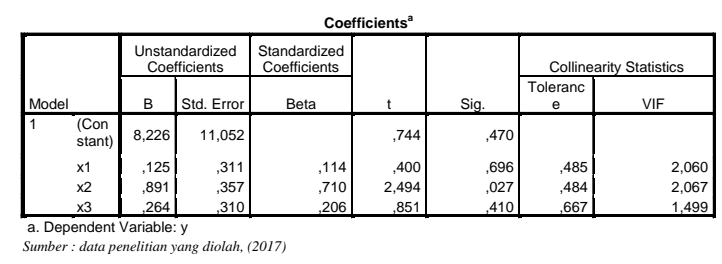

Berdasarkan tabel 3 diperoleh $\mathrm{t}$ hitung sebesar 0,400

4. Menentukan $t$ tabel

Tabel distribusi t dicari pada nilai $\alpha=0,05$

$: 2=0,025$ dan $\mathrm{df}=13$ (didapat dari rumus

$\mathrm{n}-\mathrm{k}$, dimana $\mathrm{n}$ adalah jumlah data, 17-4 =

13) kemudian mendapatkan $t_{\text {tabel }}$ dengan nilai 2,16037.

5. Kriteria pengujian

Ho diterima jika $t$ hitung $\leq \mathrm{t}$ tabel atau $-\mathrm{t}$ hitung $\geq-\mathrm{t}$ tabel

Ha diterima jika $t$ hitung $<-t$ tabel atau $-\mathrm{t}$ hitung $>\mathrm{t}$ tabel

6. Membandingkan $t$ hitung dengan tabel

Nilai thitung $>\mathrm{t}$ tabel $(0,400<2,16037)$

maka Ha ditolak.

7. Kesimpulan

Karena Nilai t hitung <t tabel $(0,400<$ 2,16037) maka $\mathrm{H}_{\mathrm{o}}$ diterima dan $\mathrm{Ha}$ ditolak, artinya secara partisial tidak terdapat pengaruh signifikan antara independensi terhadap kualitas audit.

\section{Pengalaman Berpengaruh Terhadap Kualitas} audit (Uji Statistik t)

berikut:

Langkah-langkah pengujian sebagai

1. Menentukan Hipotesis

Ho : secara partisial tidak terdapat pengaruh signifikan antara Pengalaman auditor terhadap kualitas audit.

$\mathrm{Ha}$ : secara parsial terdapat pengaruh signifikan antar pengalaman auditor terhadap kualitas audit.

2. Menentukan tingkat signifikansi

Tingkat signifikansi menggunakan $\alpha=5 \%$

3. Menentukan t hitung

Tabel 4.

Uji Koefisien Regresi Pengalaman

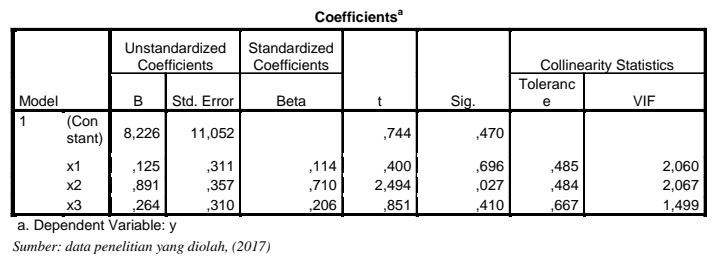

Berdasarkan tabel 4 diperoleh t hitung sebesar 2.494

4. Menentukan t tabel

distribusi t dicari pada nilai $\alpha=0.05: 2=$ 0.025 dan $\mathrm{df}=13$ (didapat dari rumus $\mathrm{n}-\mathrm{k}$, dimana $n$ adalah jumlah data, 17-4=13) kemudian mendapatkan $t_{\text {tabel }}$ dengan nilai

5. Kriteria pengujian

Ho diterima jika $t$ hitung $\leq$ tabel atau $-\mathrm{t}$ hitung $\geq$ - tabel

Ha diterima jika - $\mathrm{t}$ hitung $<-$ tabel atau $-\mathrm{t}$ hitung $>\mathrm{t}$ tabel

6. Membandingkan thitung dengan tabel Nilai t hitung > t tabel $(2,494>2,16037)$ maka Ha diterima.

7. Kesimpulan

Karena Nilai t hitung > t tabel (2.494 $>2,16037$ ) maka $\mathrm{H}_{\mathrm{o}}$ diterima dan $\mathrm{Ha}$ ditolak, artinya secara partisial terdapat pengaruh signifikan antara pengalaman terhadap kualitas audit. 


\section{Profesionalisme Berpengaruh Terhadap Kualitas Audit (Uji Statistik t)}

Langkah-langkah pengujian sebagai berikut:

1. Menentukan Hipotesis

Ho : secara partisial tidak terdapat pengaruh signifikan antara Profesionalisme auditor terhadap kualitas audit.

Ha : secara parsial terdapat pengaruh signifikan antar Profesionalisme auditor terhadap kualitas audit.

2. Menentukan tingkat signifikansi Tingkat signifikansi menggunakan $\alpha=$ $5 \%$

3. Menentukan t hitung

Tabel 5.

Uji Koefisien Regresi Profesionalisme

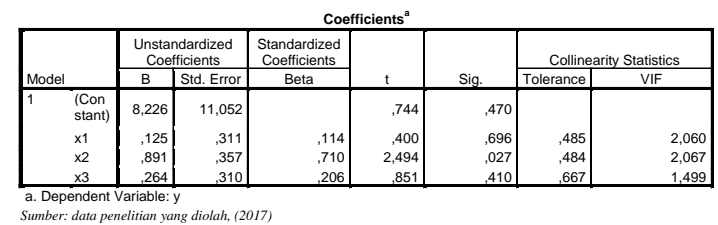

Berdasarkan tabel 5 diperoleh t hitung sebesar 0,851 .

4. Menentukan t tabel

tabel distribusi t dicari pada nilai $\alpha=$ $0.05: 2=0.025$ dan $\mathrm{df}=13$ (didapat dari rumus $\mathrm{n}-2$, dimana $\mathrm{n}$ adalah jumlah data, 17-4=13) kemudian mendapatkan $t_{\text {tabel }}$ dengan nilai 2,16037

5. Kriteria pengujian

Ho diterima jika t hitung $\leq$ tabel atau t hitung $\geq$ - tabel

Ha diterima jika - t hitung $<-$ tabel atau $-\mathrm{t}$ hitung $>\mathrm{t}$ tabel

6. Membandingkan thitung dengan tabel Nilai $t$ hitung $>\mathrm{t}$ tabel $(0,851<2,16037)$ maka Ha ditolak.

7. Kesimpulan

Karena Nilai $\mathrm{t}$ hitung $<\mathrm{t}$ tabel $(0,851<2,16037)$ maka $\mathrm{H}_{\mathrm{o}}$ diterima dan Ha ditolak, artinya secara partisial tidak terdapat pengaruh signifikan antara Profesionalisme terhadap kualitas audit.

\section{Variabel yang Paling Berpengaruh Terhadap Kualitas Audit}

Variabel Pengalaman auditor merupakan variabel yang paling dominan berpengaruh terhadap kualitas audit di bandingkan dengan variabel Independensi maupun variabel Profesionalisme, Hal ini dapat dilihat pada tabel 4 Coefficients $^{a}$ yang menunjukkan Pengalaman auditor memiliki nilai beta (standardized Coefficients) yang paling tinggi yaitu 0.710 . sedangkan nilai beta (standardized Coefficients) Independensi auditor sebesar 0,114 dan Profesionalisme auditor sebesar 0.206.

\section{Interpretasi Temuan Penelitian}

Berdasarkan hasil penelitian yang dilakukan didapatkan temuan bahwa:

1. Independensi berpengaruh signifikan tidak terpengaruh terhadap kualitas audit yang ditunjukan bahwa Nilai $t$ hitung $>\mathrm{t}$ tabel $(0,400<2,16037)$ hal ini membuktikan bahwa semakin independensi auditor tidak terpengaruh terhadap hasil kualitas audit. Tidak mudah menjaga independensi seorang auditor karena banyak yang dapat mengurangi nilai independensi seperti lamanya pengauditan, fasilitas yang diberikan klien, fee audit yang diberikan. Hal ini berarti bahwa sebagai auditor agar tidak mudah terpengaruh terhadap apapun dalam melakukan tugasnya.

2. Pengalaman auditor juga berpengaruh signifikan terhadap kualitas audit dimana dapat dilihat pada hasil Nilai $t$ hitung > t tabel $(2,494>2,16037)$ hal ini membuktikan semakin tinggi pengalaman auditor maka semakin tinggi pula kualitas audit. Oleh karena itu dengan banyaknya tugas yang telah dilakukan dan lamanya auditor bekerja akan membantu auditor dalam meningkatkan kualitas audit.

3. Profesionalisme auditor juga berpengaruh secara signifikan dengan hasil Nilai $t$ hitung $<\mathrm{t}$ tabel $(0,851<2,16037)$ semakin baik tingkat profesionalisme yang dimiliki oleh seorang auditor, maka auditor tersebut akan dengan mudah melakukan tugastugas auditnya dan sebaliknya jika 
rendah maka dalam melakukan tugasnya, auditor akan mendapatkan kesulitan-kesulitan sehingga kualitas audit yang dihasilkan akan rendah.

\section{KESIMPULAN}

Penelitian ini bertujuan untuk mengetahui apakah ada pengaruh antara Independensi, Pengalaman dan Profesionalisme auditor terhadap kualitas audit. Berdasarkan pada data yang telah dikumpulkan dan pengujian yang telah dilakukan terhadap permasalahan dengan menggunakan model regresi berganda, maka dapat diambil kesimpulan sebagai berikut:

1. Berdasarkan hasil uji regresi linier berganda ditemukan bahwa Independensi auditor tidak berpengaruh terhadap Kualitas Audit. Independensi berarti bertindak jujur, tidak memihak dan melaporkan temuan - temuan hanya berdasarkan bukti yang diperoleh.

2. Berdasarkan hasil uji regresi linier berganda ditemukan bahwa Pengalaman auditor berpengaruh positif dan signifikan terhadap Kualitas Audit. Dari hasil analisis juga diperoleh koefisien regresi yang menunjukkan bahwa pengalaman mempunyai arah pengaruh positif terhadap kualitas audit. Hal ini berarti apabila pengalaman seorang auditor semakin banyak maka akan meningkatkan kualitas audit.

3. Berdasarkan hasil uji regresi linier berganda ditemukan bahwa Profesionalisme auditor tidak berpengaruh terhadap

Kualitas Audit. Hasil tersebut menunjukan agar auditor mempunyai Profesionalisme seperti dituntut untuk memiliki tanggung jawab yang semakin besar dan sangat berperan penting dalam pemeriksaaan laporan keuangan perusahaan. Cerminan tingkah laku seorang auditor dalam hal bertindak dan berperilaku sesuai dengan etika.

4. Dalam penelitian ditemukan bahwa Variabel Pengalaman memiliki pengaruh paling dominan terhadap Kualitas Audit dibandingkan dengan Variabel Independensi ataupun Variabel Profesionalisme.

\section{Saran}

Hasil menyatakan bahwa Independensi, Pengalaman dan Profesionalisme auditor terhadap kualitas audit. Sangat penting dalam meningkatkan kualitas audit maka perlu adanya peningkatan Independensi, Pengalaman dan Profesionalisme auditor terhadap kualitas audit yang lebih baik, dengan demikian peneliti akan memberikan beberapa saran untuk peneliti selanjutnya:

1. Bagi Kantor Akuntan Publik

Seharusnya dapat lebih memperhatikan karakteristik calon pegawai baik dalam training dan recruitmen apakah sudah sesuai dengan karakteristik pekerjaan yang ada dan lebih memahami lagi tentang apa yang sedang dikerjakan dalam melakukan audit, harus lebih teliti supaya tidak terjadi kesalahan dalam pengumpulan atau pengolahan data, harus melakukan estimasi akuntansi yang masuk akal supaya tidak salah tafsir fakta, serta jangan melakukan keliruan dalam penerapan akuntansi yang berkaitan dengan jumlah klasifikasi, cara penyajian dan pengungkapan.

2. Bagi penelitian berikutnya diharapkan dapat mencari dan menemukan faktor lain yang mempengaruhi terjadinya praktek kualitas audit dan supaya jumlah kantor akuntan publik dan jumlah responden yang diteliti diperbesar dan geografis unit penelitian juga diperluas.

\section{DAFTAR PUSTAKA}

Agusti, Restu, \& Nastia Putri Pertiwi, 2013, Pengaruh Kompetensi, Independensi dan Profesionalisme terhadap Kualitas Audit. Jurnal Ekonomi. Vol.21, No.3.

Anggoro, Rusmawan W, 2013, Pengaruh Pendidikan Profesi Akuntansi, Pengalaman, Gender dan Religiositas Terhadap Kulitas Audit. Jurnal Akuntansi dan Manajemen. VOL.24 No.1.

Djara, Grace Wilhelmina, David Paul, \& Jenny Morasa, 2013, Kualitas Audit Inspektorat 
dan Opini Laporan Keuangan

Pemerintahan Daerah, Jurnal Riset

Akuntansi \& Auditing Magister Akuntansi

Fakultas Ekonomi dan Bisnis Unsrat.

Vol.4- Nomor 2.

Fietoria, Elisabeth, 2016, Pengaruh Profesionalisme, Independensi, Kompetensi dan pengalaman kerja terhadap kualitas audit dikantor akuntan publik, Bandung : Jurnal Of Accounting And Business Studies.

Fitrika Putri, 2015, Pengaruh Kompetensi, Independensi, Pengalaman \& Etika auditor terhadap kualitas audit, Ejurnal.

Ghozali, Imam, 2011, Aplikasi Analisis Multivariate dengan program SPSS, Cetakan Kelima. Semarang: BP Universitas Diponegoro.

Halim abdul, 2015, Auditing , Yogyakarta : Sekolah Tinggi Ilmu Manajemen Ykpn.

Hery, 2017, Auditing \& Asurans, Jakarta : Grasindo

Ikatan Akuntan Publik Indonesia, 2017. Directory Kantor Akuntan Publik Dan Akuntan Publik.

Jusup Al Haryono, 2014, Auditing (Pengauditan Berbasis ISA). Yogyakarta : STIE YKPN.

Kovinna Fransiska \& Betri, 2014, Pengaruh Independensi, Pengalaman Kerja, Kompetensi, dan Etika auditor terhadap kualitas audit.

Mark s.b, Alvin a, \& Randal je, 2015, Auditing \& Jasa Assurance, Jakarta : Erlangga.

Musadad Anwar, 2013, Auditing, Jakarta Penerbit: Salemba Empat

Mulyadi, 2013, Sistem Akuntansi, Edisi Ketiga, Jakarta : Salemba Empat.
Novrizah, 2010, Analisis Pengaruh Kompetensi dan Independensi Auditor terhadap Kulitas audit dengan Ukuran Kantor Akuntan Publik Sebagai Variabel Moderatin, Skripsi UIN Syarif Hidayatullah, Jakarta.

Sukrisno Agoes, Jan Hoesada, 2012, Bunga Rampai Auditing, Jakarta : Salemba Empat.

Tandiontong Mathius, 2016, Kualitas Audit \& Pengukurannya, Bandung : Alfabeta.

Theodorus M. Tuanakotta, 2013, Audit Berbasis ISA, Jakarta : Penerbit : Salemba Empat.

Tjun Tjun, Lauw, Elyzabet Indrawati Marpaung, \& Santy Setiawan, 2012, Pengaruh kompetensi dan independensi auditor terhadap kualitas audit, Jurnal akuntansi Vol.4 No.1.

William F. Messier, Steven M. Glover, \& Douglas F.Prawitt, 2014, Jasa Audit dan Assurance: Pendekatan Sistematis, Jakarta : Salemba Empat. 
